\title{
Towards an Employability Model for STEM Majors: Engagement-Based, Service-Producing, and Experience-Driven
}

\section{Dr. Faye R. Jones, Florida State University}

Faye R. Jones is a Senior Research Associate at Florida State University's College of Communication \& Information. Her research interests include STEM student outcomes and the exploration of student pathways through institutional research.

\section{Dr. Marcia A. Mardis, Florida A\&M University/Florida State University}

Marcia A. Mardis is a Professor and Associate Dean at Florida State University's College of Communication \& Information and Associate Director of the Information Institute. Author of numerous publication and recipient of over two decades of federally funded research grants, Dr. Mardis' work focuses on professional identity creation, educational text and data mining, and technician education improvement.

\section{Mr. Ebrahim Randeree, Florida State University}

Joined the faculty at the College of Communication \& Information at Florida State University (FSU) in August 2006. Previous education includes an MBA with concentrations in Health Systems Management and M.I.S. (Univ at Buffalo) and a Bachelor of Science in Computer Science (Rochester Institute of Technology). Research focus in STEM Education, Health Informatics, and Technology Adoption; teaching focus in leadership, career prep, health informatics, and technology. 


\title{
Towards an Employability Model for STEM Majors: Engagement-Based, Service-Producing, and Experience-Driven
}

\begin{abstract}
In this theoretical work-in-progress paper, we present Employ-STEM, a mentored employability model for science, technology, engineering, and mathematics (STEM) majors which integrates foundational concepts of experiential learning to enhance students' educational experiences beyond the classroom, develop employability skills, and culminate in employment. The premise of this model is that, under the guidance of a faculty mentor, students benefit from three main learning opportunities: 1) experiential leadership development, which requires placing students in opportunities that allow them to practice leading; 2) service learning, which provides opportunities for learning through interactions with communities, schools, and non-profit organizations; and 3) experiential learning, which covers work-integrated learning, internships, apprenticeships, and other hands-on activities. These engagement opportunities are consistent with Tinto's theory of student integration, which postulates that academic and social integration are key factors for increasing student persistence and graduation. Through a synthesis of the main facets of these theory-based approaches, we will: 1) describe an employability model for STEM majors, 2) illustrate important elements of this model; 3) share two vignettes which incorporates elements of the Employ-STEM model; and 4) identify next steps to improve and test the model.
\end{abstract}

\subsection{Introduction}

The need for skilled laborers is increasing in the STEM fields, especially in disciplines where continuous advancements in systems, technologies, and processes require employees that are able to adapt to change [1]. Highly skilled technicians who are resilient, and capable of solving complex, and not just routine, issues are valued in the workplace [2], [3]. Dynamic fields require divergent employees, who can work independently and with a team, handle routine and complex issues, work behind a work station and speak with customers [1]. Additionally, if employers are to pay higher rates for these skilled technicians, they will continue to seek employees with knowledge that extends beyond the theoretical concepts learned in the classroom, graduates who can apply concepts, teach them to others, and who possess the qualities and work-ethic of leaders [4]. As a result, students who are able to demonstrate that they have acquired the skills and qualities of leaders are at an advantage over those who have just learned basic skills [5].

Educators are increasingly expected to ready students for college and career; these skills transcend content knowledge but also provides students with employability skills that will enable them to quickly adjust to their new roles and be prepared to adapt and further their careers [6]. Gaining employability skills requires a mentor's commitment to exposing students to and engaging them in activities and situations that provide them with opportunities to learn [7]. In this paper we propose an employability model to enable educational leaders to supplement their STEM programs with strategically placed and designed informal learning experiences to assist students in developing employability skills. 


\subsection{Literature Review}

Experiential learning opportunities are valuable for gaining employability skills; while leadership skills are also a core element of college and career readiness, engagement is the central pillar shared by this concepts.

\subsection{Engagement}

Over the past 40 years, educational researchers and policymakers have considered Tinto's [8] theory of student integration as a way to explain the importance of retaining students in college by engaging and integrating them academically and socially into academic life. The theory postulates that students become committed to their personal goals and the institution through both formal and informal engagement activities. Informal activities involve peer and faculty interactions outside the classroom, while intellectual development encompasses the formal learning (i.e., the classroom) environment. Tinto's theory does not exclude using classrooms as sites to develop outside experiences, but instead suggests that for students to feel as though they "belong" to their college institutions, their experiences have to extend beyond the classroom and fulfill their academic and social needs.

\subsection{Engagement-based learning}

2.2.1. Experiential learning. Experiential learning allows students to apply specific concepts learned in the formal environment to the informal environment through opportunities such as internships, apprenticeships, competitions, clubs, practica, and cooperative education [9]. According to Kolb and Fry [10], experiential learning theory is a four-part cycle.

1. The learner has concrete experience with the content being taught.

2. The learner reflects on the experience by comparing it to prior experiences.

3. Based on experience and reflection, the learner develops new ideas about the content being taught.

4. The learner acts on the new ideas by experimenting in an experiential setting.

Experiential learning encourages student reflection and experimentation and offers a safe place for students to apply concepts or techniques they have learned in the classroom, and even allows them a safe haven to fail [11]. These types of engagement opportunities are based in authentic scenarios. Experiential learning experiences produce transferable skills, such as communication, problem-solving, and civic behaviors [12]. Competitions, in fields such as engineering and IT promote interest in certain disciplinary domains and encourage teamwork [13]. Employers value the "blend of technical and general skills and hands-on experience" [14, p. 929] that result from experiential learning; for this reason, employers have called for formal curricula to include these experiences in order for course content to be more aligned with workplace needs [15].

2.2.2. Service learning. Related to experiential learning, service learning offers students the ability to learn through experience; service learning is not volunteerism, community service, internships, or field education [16]. Service learning is learning while "educating the heart" [17], and reflects a pedagogy that integrates academic learning with community-based work [18]. Most importantly, because external stakeholders are integral partners, service learning benefits 
both the student and the community [19]. Experiential education and democracy also serve as the philosophical underpinnings of service learning [20]. A true service learning engagement opportunity requires six key components: 1) an instructor or facilitator, 2) a community partner, 3) a student, 4) academic context, 5) reflective thinking, and 6) meaningful service. An example of a service learning project is when an engineering major has been assigned to a local high school to assist students to prepare for a robotics competition. In this situation, the service is providing a learning opportunity to the provider of the service and the recipients of the service (to include the high school students and the teacher).

Service learning enhances students' academic and civic engagement through a combination of traditional learning activities and community services. Often civic involvement is one of the important student-learning outcomes in service learning projects [19]. Service learning also allows students to gain an understanding of how to work with and respect people different from themselves [17]. The ability to work with others, and especially in team-based STEM fields, is a valuable employability skill [4].

2.2.3. Experiential leadership. Becoming a leader also requires some hands-on experience. Leadership opportunities help to develop important employability skills. Experiential leadership, the process of educating, developing and inspiring people using a hands-on approach through individual and team participation, can develop employability skills that are noticeable in direct contact with employers [21]. When students are positioned and empowered to lead in formal and informal environments, they experience enhanced self-assurance in group leadership, increased sensitivity to issues of diversity, and willingness to engage in culturally competent practice [22]. Students who have the opportunity to gain leadership experience before entering the workforce are able to try different leadership approaches, learn how to handle difficult situations, and determine which styles work best for themselves [23].

\subsection{Mentoring}

In an educational context, a mentoring relationship is also described "as one that may vary along a continuum from informal/short-term to formal/long-term in which faculty with useful experience, knowledge, skills, and/or wisdom offer advice, information, guidance, support, or opportunity to another faculty member or student for that individual's professional development" [24, p. 67]. Meaningful, sustained student-faculty interactions are important for promoting positive learning outcomes [25]. Specifically, high-quality interaction with faculty both in and outside the classroom is an important determinant of student learning [23], yet professors spend 2-6\% of their time working one-on-one with students, especially undergraduates [26], [27]. According to the latest faculty survey conducted by the Higher Education Research Institute [29], 79\% of faculty believed they should prepare their students for employment, while only 1 in 5 actually did. This suggests that mentoring undergraduates may require reprioritization of other competing assignments by both faculty and their institutions if faculty truly believe that they should be providing this type of mentoring [28]. 


\subsection{Employability Skills}

The definition of employability skills is broad and includes communication, entrepreneurship, team work, problem solving, emotional intelligence, self-assessment, and analysis, among other skills [24]. Postsecondary educators recognize employability skills as important competencies needed by students to attain employment upon graduation [29]. Educators use various approaches to assist their students in gaining these valuable skills, such as the use of STEM outreach activities in informal learning environments [30], and collaborating with employers to provide students with opportunities to attain these skills [31].

The extent to which students demonstrate employability skills is also key to many STEM programs' survival. For example, the Carl D. Perkins Vocational and Technical Act of 1998 [32] requires performance measures to quantitatively assess career and technical education (CTE) program outcomes like employment. Many states have performance-based educational budget formulas that focus on student employment outcomes as measures for funding postsecondary institutions. As a result, a focus on the mechanisms, processes, and programs that can increase the number of students successfully completing their degrees and gaining meaningful employment, presumably through the exercise of employability skills, is as a legislative mandate and priority [33].

\subsection{Conceptual Framework}

In Figure 1, we illustrate the Employ-STEM model, which integrates concepts of engagement, mentoring, and industry participation to increase the technical and employability skills that are valued by employers. This model can be applied to most STEM disciplines, and is reflective of what learners should experience by the time they are accepted to their STEM major.

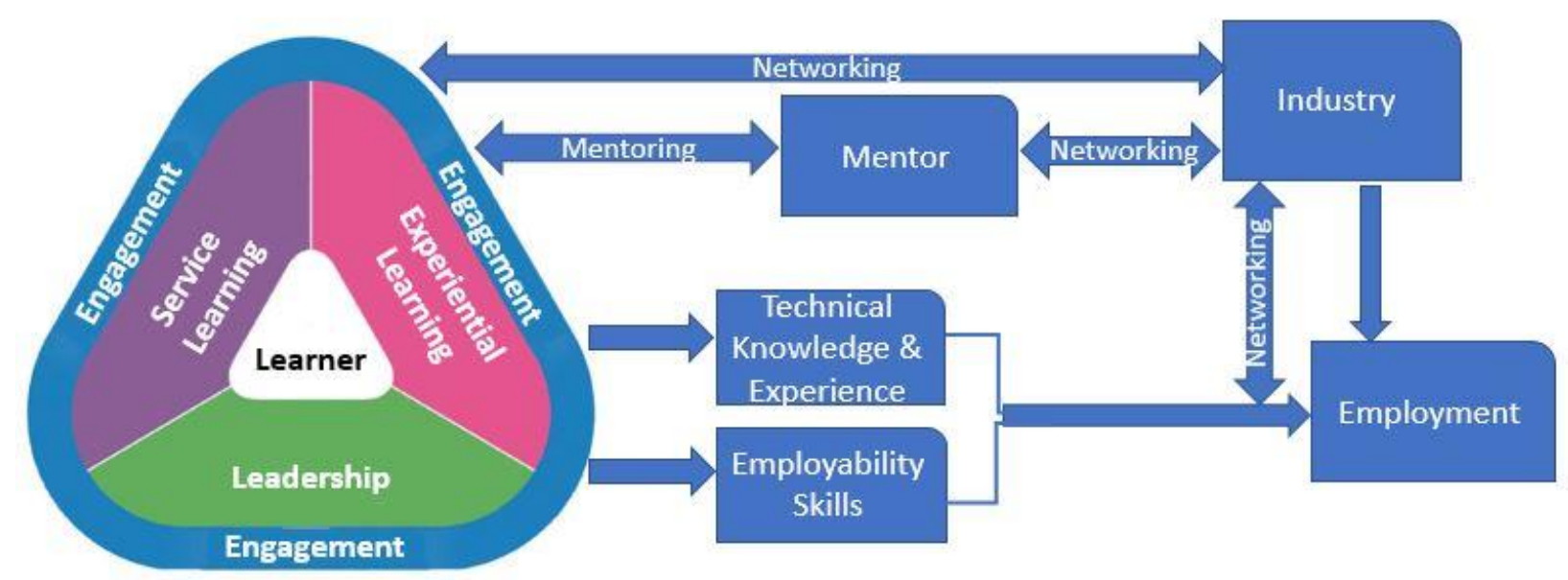

Figure 1. An Employability Model for STEM Majors (Employ-STEM)

As Figure 1 shows, engagement opportunities in the Employ-STEM model take the form of service learning (e.g., work at schools, churches, nonprofit organizations, or other service projects), experiential learning (e.g., internships, apprenticeships, employer visits, career fairs, 
etc.), and/or experiential leadership (e.g., STEM club leader, team leader, design leader, team spokesperson, etc.). These experiences are directed by a faculty member with expertise, experience, and connections with the industry. Students report to the mentor, debrief, reflect on the experiences they have had, and are sent on continuous assignments until they graduate. These assignments are tailored to students' specific areas of weakness, but also aid in strengthening skills that the students already possesses.

The outcomes of engagement in Employ-STEM are to 1) increase students' employability skills, and 2) develop or enhance technical knowledge by applying learned classroom concepts to informal learning environments through experiences. These engagement activities also provide heightened exposure and contacts with industry members, allowing for greater opportunities for students to network with employers. Similarly, the mentor, who is in contact with both students and employers are able to align employers' needs with student talents and communicate to employers about students which might be best poised for jobs that are being offered. Educators can use this simple, but dynamic, engagement model to foster graduates who are more likely to be offered a job over students who have not experienced the engagement activities.

\subsection{Employ-STEM Vignettes}

Although Tinto's theory focuses on postsecondary students who enter in their freshman year, these concepts are easily transferrable to students when they enter their major. Just as freshman need to be integrated into college campuses, students entering their majors must also be academically and socially integrated into their chosen field. Students must learn theories, concepts, processes, tools, and applications in the formal learning environment, just as they must interact with faculty and peers in the informal environment to feel a sense of "belonging" to their selected discipline or major. Tinto's theory is an important first step in explaining the EmploySTEM model because student engagement is a continuous process that extends beyond the first year and through employment. Two short vignettes illustrate the Employ-STEM model:

3.1.1. Shy Sally. Sally is a transfer student from a local community college who was recently admitted to a mechanical engineering program at a large research-intensive university in her home town. She excels academically, but is scared to engage in social activities, and often asks others to present group products and presentations. At her university's Industry Day, Sally was too shy, even after hours of preparation, to share the solar-powered panel for a generator that she built! She lurked behind the table, not making eye contact with anyone who stopped to examine her invention. A faculty member attending the Industry Fair noticed Sally's reticence and encouraged her to become a college ambassador. The faculty member mentored college ambassadors, to go in teams of three to local schools to help students build robots for statewide competitions; he thought participating in these visits would be a beneficial service learning opportunity for Sally. On her first day of the school visits, Sally was terrified but introduced herself many times to the engineering teachers, individual students, and administrators. Sally began to feel more comfortable with engaging with people she had never met.

Sally was terrific at assembling and configuring the robots, but at first, she would do it so quickly that the high school students kept saying that they were lost and asked her to explain her process. Sally was convinced that she had also explained the robot configuration process 
numerous times, but realized that she needed to engage with the students more slowly, and explain each step. When the students then began to readily following Sally's example, she was thrilled and realized that she was able to teach the students the skills they needed to assemble and operate their robots. Sally reflected on her day and felt proud of her ability to help the students; she looked forward to sharing this experience with her faculty mentor. By the end of that academic year, Sally was so confident in providing clear instructions, answering questions, and working with the high school students to solve problems that her mentor asked her to join the ambassadors who were sharing their service learning experiences with faculty and students from across campus on Student Innovation Day. This event would be attended by the college's professors and students, whom would go to different booths to hear about student innovation projects. Sally had over 30 encounters with faculty and other students, and upon reflection was convinced that she could talk about her project with her eyes closed.

The following semester, not only was she able to present her solar panel on Industry Day, but her clear explanation and enthusiasm led a company representative to contact her faculty member to discuss sponsoring her capstone project. Sally was also made leader of the school-based service learning project in which she had to contact teachers to set-up attendance days, email team members to ensure they could attend, and act as the spokesperson and reporter for her group (experiential leadership). The teachers all knew Sally from her great work and positive outcomes and were eager to work with her again; her fellow ambassadors were excited to join with Sally in what they knew would be organized and efficient trips to local schools.

With her faculty mentor's guidance and support, Sally used her experiences to transform into a great communicator, an effective team member, and strong leader (e.g., employability skills). She fearlessly attended every Industry Day and career fair (e.g., experiential learning and networking) to share her generator idea and meet employers that were interested in her work. By the time she was a senior, two employers from her Industry Day network offered her two mechanical engineering positions--before she even graduated! The Employ-STEM model allowed Sally to set aside her self-doubt gradually, and find comfortable, important ways to build her confidence and show her skills to local employers.

3.1.2. Confused Corey. Corey had always wanted to be an information technology (IT) major, and now he was in his junior year at a four-year institution. Corey attended every lecture, completed every assignment, and diligently read his course materials; he had a theoretical understanding, but was lost when teachers and his fellow students would talk about their handson experiences in the IT field. Although he had always been interested in IT, Corey had never been around IT other than his own computer. While many of his classmates had been working at entry level IT jobs since high school, Corey came from a single-parent family and he had never had a job because he needed care for his younger siblings while his mom was at work. Because he was the first in his family to attend college, Corey wanted to graduate with honors and obtain a high paying, exciting IT job. But the more Corey heard his classmates always talk their IT experiences, the more he understood that he was only "book smart." He had little confidence that he could actually apply the content he had read and heard about in lectures. This fear was realized for Corey when he botched a simple hands-on server assembly activity. He started to doubt himself and told one of his professors that perhaps an IT major was not for him. 
While Corey's professor did note that he was having trouble in the hands on activity, he applauded Corey's keen interest in IT and suggested that Corey get experience in troubleshooting and resolving common user complaints. His professor assured him that he would do well in the field, and arranged for Corey to have a paid internship with the college's IT help desk (experiential learning). At first, Corey followed the on-board technicians everywhere they went. Every day he learned something new, and after a few months, he resolved some of the customer issues easily on his own. After his second semester working at the help desk, the other technicians started to trust that Corey could respond to calls on his own. In his third semester, he was asked to train a new technician for the IT helpdesk (experiential leadership). Corey was more confident in class, volunteering answers to questions and hands on demonstrations when the opportunities arose. He began using technical vocabulary like the other students (and sometimes his was even more advanced). Corey went from knowing theoretical concepts to being and experienced troubleshooter with the "book smarts" and experience to identify a problem, understand why the problem occurred, fix the problem, and prevent the problem from happening again. His confidence improved and he was able to articulate his technical knowledge with ease; Corey's perfect attendance record and excellent work ethic even gained him the Employee of the Month pizza party (employability skills).

Corey's professor set up a "Job Hop" for students to meet local IT employers at their company sites. Corey was excited to see inside some of the local tech companies and enthusiastically signed up. During Job Hop, Corey got to meet and speak with several employers (networking); an employer from the local electric company gave Corey a business card and said to call if he wanted a job. However, Corey was a bit intimidated by the idea of working in the electric company's IT department since he had only worked at the college help desk, so his mentor called the local electric company to inquire about Corey working as an intern during his last semester before graduation (a benefit of mentor networking). The employer remembered Corey and said that he would love to have Corey on site to "show him the ropes" of the IT department. The internship went well, Corey fit in well at the IT department, and upon graduation, the employer offered Corey a full-time position - at a salary far beyond what expected. By working with his faculty mentor and engaging in the Employ-STEM model, Corey achieved his goal!

\subsection{Conclusion and Next Steps.}

The Employ-STEM model is emerging, but holds promise as a roadmap for helping to increase the employability of students. Employ-STEM is an initial attempt to assist faculty and other college personnel in their efforts to improve students' employment outcomes.

Out next steps for the developing model include addressing these key questions:

- What are the best approaches for increasing the number of faculty willing to serve as faculty members? What are other options for ensuring that qualified STEM faculty participate?

What is the best way to staff the Employ-STEM model? For example, is it more effective for colleges to dedicate staff to assist with these engagement opportunities and industry partner activities, or should each faculty be tasked (in some way) with these types of undergraduate mentoring activities?

- How should the Employ-STEM engagement experiences be integrated into an academic program? Is it more effective for these activities be required or optional for students? 
- What are the other major factors that should be integrated into the model?

- What are appropriate metrics to test and assess the Employ-STEM model?

The Employ-STEM model is a framework for developing employability skills and gaining experience in concepts learned in the classroom. The engagement activities are tailored to the individual student, and allows students to develop or improve their technical knowledge while also acquiring the employability skills that they may lack. Of importance is the STEM faculty member who serves to advise and guide students, while also developing partnerships with employers both locally and in nearby locations. The model provides many key benefits to the students, and is likely to increase the number of students with jobs upon graduation, a benefit to the institution as well. 


\section{References}

[1] National Academies of Sciences, Engineering, and Medicine, Graduate STEM education for the 21st century. Washington, DC: The National Academies Press, 2018.

[2] A. Bargagliotti, D. Herreiner, and J. A. Phillips, "Breaking boundaries: Presing issues in equity, computing, and problem-solving in STEM undergraduate education," J. Res. STEM Educ., vol. 4, no. 1, pp. 2-12, Jul. 2018.

[3] AAC \& U, College learning for the new global century. Washington, DC: The Association of American Colleges and Universities, 2007.

[4] S. Ricker, "The skill set more than 3/4 of employers want," 10-Apr-2014. [Online]. Available: https://www.careerbuilder.com/advice/the-skill-set-more-than-of-employerswant. [Accessed: 25-Apr-2019].

[5] M. Akdere, L. Hickman, and M. Kirchner, "Developing leadership competencies for STEM fields: The case of Purdue Polytechnic Leadership Academy," vol. 21, no. 1, pp. 49-71, 2019.

[6] E. Cushing, D. English, and S. Therriault, "Developing a college- and career-ready workforce: An analysis of ESSA, Perkins V, IDEA, and WIOA," AIR American Institutes for Research: Brief, 24-Apr-2019. .

[7] C. Bitter and E. Loney, "Deeper learning: Improving student outcomes for college, career, and civic life," American Institues for Research: Brief, 24-Apr-2015. .

[8] V. Tinto, "Dropout from higher education: A theoretical synthesis of recent research," Educ. Res., vol. 45, pp. 89-125.

[9] D. Kolb, Experiential learning: Experience as the source of learning and development. Englewood Cliffs, NJ: Prentice Hall, 1984.

[10] D. A. Kolb and R. E. Fry, "Toward an applied theory of experiential learning," in Theories of group processes, C. Cooper, Ed. New York: John Wiley \& Sons, 1975.

[11] H. S. Kuk, Ed., "A dissection of experiential learning theory: Alternative approaches to reflection.," Adult Learn., vol. 29, no. 4, pp. 150-157, 2018.

[12] J. H. Fede, K. S. Gorman, and M. E. Cimini, "Student employment as a model for experiential learning," J. Exp. Educ., vol. 41, no. 1, pp. 107-124, 2018.

[13] M. Gadola and D. Chindamo, "Experiential learning in engineering education: The role of student design competitions and a case study," Int. J. Mech. Eng. Educ., vol. 47, no. 1, pp. 3-22, 2019.

[14] J. M. Hollister, L. I. Spears, M. A. Mardis, J. Lee, C. R. McClure, and E. Liebman, “Employers' perspective on new information technology technicians' employability in North Florida," Educ. Train., vol. 59, no. 9, pp. 929-945, 2017.

[15] F. Ghemri, A. Bouras, and H. Gasmi, "Framework of experiential learning to enhance student skill," in Framework of experiential learning to enhance student skill, Kuala Lumpur, Malaysia, 2017.

[16] S. Lim and C. Bloomquist, "Distinguishing service learning from other types of experiential learning," Educ. Inf., vol. 31, pp. 195-207, 20152014.

[17] F. Florence, McCarthy, "Service-learning: New dimensions to usual practice," in SHS Web Conference, SHS Web Conf., 2018, vol. 59.

[18] W. Oakes, J. Duffey, T. Jacobius, P. Linos, W. W. Schults, and A. Smith, "Service-learning in engineering," in 32nd Annual Frontiers in Education, Boston, MA, 2002. 
[19] D. E. Giles and J. Eyler, "The theoretical roots of service-learning in John Dewey: Toward a theory of service-learning," Serv. Learn. Gen., vol. 150, 1994.

[20] J. Dewey, Democracy and education. New York: Collier Books, 1916.

[21] M. McCall, "Leadership development through experience," Acad. Manag., vol. 18, no. 3, 2004.

[22] B. Banach, E. Foden, and V. Brooks Carter, "Educating undergraduate group workers: Increasing confidence through experiential learning," Soc. Work Groups, vol. 42, no. 2, pp. 158-170, 2019.

[23] Center of Inquiry in the LIberal Arts at Wabash College, "Wabash National Study of Liberal Arts Education: High-impact practices and experiences from the Wabash National Study." 2013.

[24] R. A. Berk, J. Berg, and R. Mortimer, "Measuring the effectiveness of faculty mentoring relationships," Acad. Med., vol. 80, no. 1, pp. 66-71.

[25] E. McKinsey, "Faculty mentoring undergraduates: The nature, development, and benefits of mentoring relationships," Teach. Learn. Inq., vol. 4, no. 1, pp. 1-15, 2016.

[26] J. F. Milem, J. B. Berger, and E. L. Dey, "Faculty time allocation: A study of change over twenty years," J. High. Educ., vol. 71, no. 4, pp. 454-475, 2000.

[27] R. Olwell, "Moving beyond 2 percent," Inside Higher Education, 2017.

[28] E. B. Stolzenberg et al., Undergraduate teaching faculty: The HERI faculty survey 20162017. Los Angeles: Higher Education Research Institute, UCLA, 2019.

[29] G. Baker and D. Henson, "Promoting employability skills development in a researchintensive university," Educ. Train., vol. 52, no. 1, pp. 62-75, 2010.

[30] J. M. Sinclair, S. C. H. Allen, L. Davis, T. Goodchild, J. Messenger, and S. J. Turner, "Enhancing student employability skills through partnership working in STEM outreach: The University of Northampton approach," in Enhancing the STEM Student Journey, University of Edinburgh, 2014.

[31] S. O'Leary, "Collaborations in higher education with employers and their influence on graduate employability: An institutional project," Enhancing Learn. Soc. Sci., vol. 5, no. 1, pp. 37-50, 2013.

[32] U.S. Department of Education, "Carl D. Perkins vocational and technical education act of 1998," Archived Information, 2003. [Online]. Available: https://www2.ed.gov/offices/OVAE/CTE/legis.html.

[33] E. MacKellar, "Performance-based budgeting in the states," National Conference of State Legislators [NCSL], vol. 24, no. 35, 2016. 